show the production possibilities of tractors and related equipment. The wide use of trucks and tractors is changing our previous conception of the terms merchantable and accessible timber. The tractor in present woods" operations is the most flexible and valuable piece of logging equipment.

The chapter on power logging was written by Professor J. Kenneth Pearce of the University of Washington, acknowledged as the leading West Coast authority on this subject. Several Canadians have made contributions to the book in the form of information and data, namely, A. M. Koroleff of the Canadian Pulp \& Paper Association of Montreal, L. A. Nix, consulting forester, Toronto, I. F. Fogh, Canadian International Paper Co., Three Rivers, Que., and G. E. Knapp, Department of Forestry, University of British Columbia.

The book is a well-written text both as to the treatment of the subject and as to scope.

Reviewed by A. S. MrCHELL.

\title{
UNIVERSITY OF NEW BRUNSWICK SCHOLARSHIPS
}

Two scholarships which the late Viscount Bennett, famous son of New Brunswick who became Prime Minister of Canada, made available to the University of New Brunswick have been awarded for the academic year now in progress.

George J. Garner of Stratford, Ont., successfully competed for the first scholarship. A naval officer during the war, he is another student veteran whose academic record at U.N.B. has been consistently good. Garner is also a prominent athlete on the campus; he has won a letter for participation in varsity basketball every year since he came to college. $\mathrm{He}$ is a senior.

The second Bennett scholarship was also won by a student from Ontario, George A. Hamilton of Markstay. Only 20 years of age, Hamilton has been successful in his bid for leadership in a large student body which includes hundreds of older student veterans. $\mathrm{He}$ is a student of the junior year.

Each of the Bennett scholarships has a value of $\$ 100$. By terms of Viscount Bennett's trust the scholarships must be awarded to forestry students.

\section{UNIVERSITY OF TORONTO SCHOLARSHIPS}

P. J. Pointing and J. L. Ladell have won Forest Industries Entomological scholarships worth $\$ 200$ each, Dr. Sidney Smith, president of the University of Toronto, has announced.

Philip Pointing is enrolled in fourth year Forestry. He is 21 years old and lives in Toronto. During the summer of 1948 he worked on forest insect investigations with the Ontario Department of Lands and Forests.

John Ladell is in second year Forestry. He is 24 years old and came to Canada from England after five years service in the Royal Navy. During the summer of 1948 he worked at the Forest Insect Laboratory of the 